\title{
4. SEISMIC REFLECTION PROFILES ON THE BLAKE RIDGE NEAR SITES 994, 995, AND 9971
}

\author{
William P. Dillon, ${ }^{2}$ Deborah R. Hutchinson, ${ }^{2}$ and Rebecca M. Drury ${ }^{2}$
}

\begin{abstract}
Seismic reflection profiles near Sites 994, 995, and 997 were collected with seismic sources that provide maximum resolution with adequate power to image the zone of gas hydrate stability and the region directly beneath it. The overall structure of the sediment drift deposit that constitutes the Blake Ridge consists of southwestward-dipping strata. These strata are approximately conformal to the seafloor on the southwest side of the ridge and are truncated by erosion on the northeast side. A bottom-simulating reflection (BSR) marks the velocity contrast between gas hydrate-bearing sediment and regions containing free gas beneath the zone of gas hydrate stability. The BSR is strong and continuous near the ridge crest but becomes discontinuous on the flanks, where concentration of gas is reduced and dipping strata pass through the level of the base of gas hydrate stability or the strata are disrupted by faults. Seismic reflection amplitudes appear to be reduced in the region of gas hydrate formation compared to normal amplitudes. A faulted zone $~ 0.5-0.6 \mathrm{~s}$ thick parallels reflections from strata. We infer that this may represent a formerly gas hydrate-bearing zone that was faulted because of a breakdown of hydrate near its phase limit (at the base of the zone). Strong reflections at the top of the faulted zone are caused by free-gas accumulation at Site 994. Similar strong reflections probably are caused by free-gas accumulations where the top of the faulted zone rises above the BSR, although this would require local free gas within the hydrate-stable zone.
\end{abstract}

\section{INTRODUCTION}

This paper presents the regional structure of the Blake Ridge in the vicinity of Ocean Drilling Program (ODP) Sites 994, 995, and 997 , as interpreted from air gun seismic reflection profiles. The profiling system was designed to provide maximum resolution for the upper $1-1.5 \mathrm{~s}$ of traveltime of the sedimentary section, which is the region that includes the zone of gas hydrate stability and deeper gas accumulation.

The Blake Ridge extends seaward (southeastward) across the continental rise and abyssal seafloor approximately normal to the continental margin off South Carolina (Fig. 2, "Introduction" chapter, this volume). It is a large deep-ocean sediment drift that has accumulated on an unconformity of early Oligocene age known as horizon $\mathrm{A}^{\mathrm{u}}$ (Mountain and Tucholke, 1985), and it is continuing to accrete and migrate as a result of interactions of deep-sea currents - dominantly southward-flowing contour currents (Bryan, 1970; Markl et al., 1970; Hollister, Ewing, et al., 1972; Buffler et al., 1978; McCave and Tucholke, 1986). The Blake Ridge is built above oceanic crust (Klitgord et al., 1988) off the southern part of the Carolina Trough (Hutchinson et al., 1982; Dillon and Popenoe, 1988). The trough is marked by a series of diapirs along its seaward side, one of which rises into the sediments at the landward end of the ridge (Dillon et al., 1982). Workers have noted unusually strong indications of gas hydrate in seismic reflection profiles on the Blake Ridge for many years (Stoll et al., 1971; Ewing and Hollister, 1972; Hollister, Ewing, et al., 1972; Lancelot and Ewing; 1972; Tucholke et al., 1977; Shipley et al., 1979; Dillon et al., 1980; Paull and Dillon, 1981; Dillon and Paull, 1983; Kvenvolden and Barnard, 1983; Krason and Ridley, 1985; Rowe and Gettrust, 1993; Katzman et al., 1994; Lee et al, 1994; Dillon et al., 1993, 1994, 1995). Leg 164 represented the third scientific

Paull, C.K., Matsumoto, R., Wallace, P.J., et al., 1996. Proc. ODP, Init. Repts., 164: College Station, TX (Ocean Drilling Program).

${ }^{2}$ U.S. Geological Survey, Woods Hole, MA 02543, U.S.A. Dillon: bdillon@nobska.er.usgs.gov drilling cruise to sample gas hydrate on the Blake Ridge and involved the most extensive geophysical data gathering; previous drilling was associated with Deep Sea Drilling Project Legs 11 and 76 (Hollister, Ewing, et al., 1972; Sheridan, Gradstein, et al., 1983).

\section{DATA}

Seismic profiles shown in this paper were collected using moderately small, high-pressure, pneumatic seismic sources to penetrate to below the region of gas hydrate stability but maintain the best possible resolution. Profiles collected in 1992 used a $160-$ in $^{3}(2.62 \mathrm{~L})$ air gun, whereas profiles collected in 1995 employed a generatorinjector gun in which the generator chamber (which generates the primary signal) was $105 \mathrm{in}^{3}(1.72 \mathrm{~L}$ ) and the injector chamber (which controls bubble pulsing) was also $105 \mathrm{in}^{3}$. Data were recorded digitally with 2-ms sampling. Profile locations are shown in Figure 1. Two long profiles, USGS $92-11$ and USGS 92-12, collected in 1992, cross the entire ridge in the vicinity of Sites 994, 995, and 997 (profiles: Figs. 2, 3; interpretations: Figs. 4, 5). Several shorter profiles, collected in 1995 while shooting for vertical seismic profiles (VSPs) at Sites 994 and 997 tie these profiles to the drill sites (Figs. 6-9; also see Fig. 1 in Section 2, this volume). Processing of data included debias, predictive deconvolution, band-pass filtering $(8-160 \mathrm{~Hz})$ with a notch filter $(8-12 \mathrm{~Hz})$, and true amplitude recovery; 1992 lines were migrated, and 1995 lines were not.

\section{INTERPRETATION OF PROFILES Overall Structure}

The overall structure of the Blake Ridge is that of a southwestward-migrating sediment drift. All reflections dip toward the southwest (downdrift) side of the ridge and are approximately parallel to the seafloor on that side, whereas those on the northeast side are truncated at the seafloor (Figs. 2-5). As a result of the truncation, older strata crop out on the lower part of the northeast flank, forming dif- 


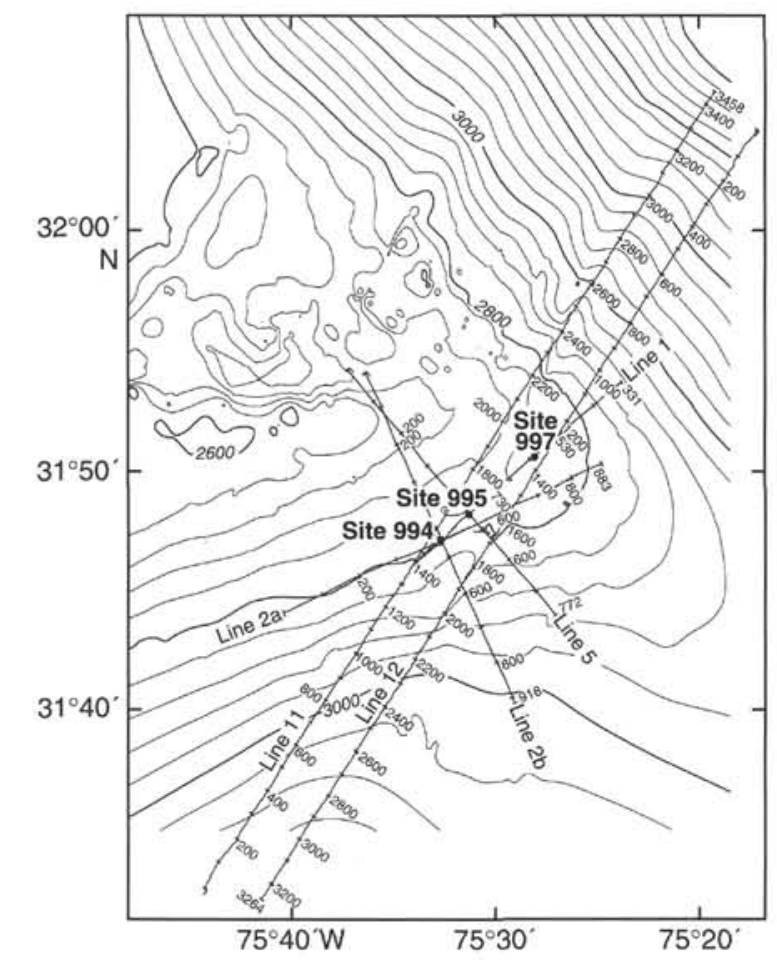

Figure 1. Locations of seismic reflection profiles presented in this paper. Lines 11 and 12 were collected in 1992; the remainder, in 1995.

ferentially eroded, rough seafloor. On the upper part of the northeast flank, the eroded, dipping strata terminate at an unconformity that is covered by strata of possibly Pleistocene age that are conformal to the seafloor.

\section{Reflection Features Associated with Gas Hydrate Bottom-Simulating Reflection}

A region of weak reflections just below the seafloor, $\sim 0.5-0.6 \mathrm{~s}$ thick, is marked at its base by a strong reflection or set of reflections that parallel the seafloor and are known as the bottom-simulating reflection (BSR). A single strong BSR that appears continuous at these frequencies $(\sim 12-180 \mathrm{~Hz})$ exists only near the crest of the ridge (Figs. 2, 3; indicated by a continuous line with circles in the interpretations on Figs. 4, 5). Elsewhere, the BSR is marked by a series of strong but horizontally discontinuous reflections (marked by X; Figs. 4,5 ). This series of reflections would appear as a continuous BSR in profiles filtered for lower frequencies (Lee et al., 1994) and also will be referred to as the BSR.

The BSR is considered to mark the shallowest limits of strata that contain free gas-above this level, gas is included in gas hydrate, which may form a high-velocity cement in the sediment and enhance the velocity contrast with the low velocities caused by presence of free gas (Brandt, 1960) that exists below the hydrate phase boundary. Where the BSR is continuous (Figs. 2, 3), we infer that the sediments are filled with free gas, although the lack of a reflection from a flat bottom of the gas layer (so-called "bright spot") and analyses by Katzman et al. (1994) suggest that the gas-saturated zone on the Blake Ridge is thin $(<25 \mathrm{~m})$ with a gradational base. Where the BSR is discontinuous, as on the flanks of the ridge (Figs. 2,3), gas concentration probably is less, and discontinuities seem to have two alternative causes. In some cases, a series of dipping strata passes through the level of the hydrate phase boundary, and significant amounts of free gas in the more porous strata, alternating with little gas in less porous layers, cause variations in reflection strength. This creates a shin- gled appearance to the BSR. In other cases, minor faulting has fractured the strata, creating disruptions in gas trapping and, hence, in the BSR, as is indicated in an enlarged view of part of Profile 92-12 (Fig. 10; the BSR is marked X, as it is in the interpretation in Fig. 5; the location of Fig. 10 is indicated by the photo corner bracket in Fig. 5). An expanded plot of 100 shots (Fig. 11; location indicated on Fig. 10) shows more clearly the relative reflection strengths at the BSR (at $\sim 4.7 \mathrm{~s}$ ) and in the regions above and below it. The polarity of the seismic wave also can be observed in this plot. At the seafloor, the seismic wave passes from lower to higher acoustic impedance (primarily because of an increase in density), and at the BSR the wave would be expected to pass from higher to lower acoustic impedance (because of the lower velocity associated with the presence of free gas in the sediment). Thus, the reflections at the seafloor and BSR would be expected to display reversed polarity, but they do not appear to do so in this case.

The BSR appears shallower by $\sim 0.05 \mathrm{~s}$ on the northeast side of the ridge compared to similar water depths on the southwest side (Figs. $2,3)$. Two factors might explain this difference. Higher sediment velocities on the northeast side would produce shallower time depths for equivalent real depths. Such higher velocities might be anticipated on the northeast side because the sediments there have been subjected to compaction by overburden that was subsequently removed by erosion, and therefore they may be overcompacted. Velocity studies using ocean-bottom hydrophones seem to support this hypothesis (fig. 6 in Katzman et al., 1994). Alternatively, the thermal gradient may be greater on the northeast side, which would raise the base of gas hydrate stability. An increased thermal gradient could result from circulation of fluids squeezed out of the compacting sediments of the ridge. These warm fluids from greater depths might be expected to preferentially flow along stratal pathways, which would cause them to be expressed from the ridge dominantly toward the north. Measurements in a transect across the ridge (Ruppel et al., 1995) provide a weak indication of increased thermal gradients toward the northeast.

\section{Seismic Amplitude Reduction-Blanking}

The amplitudes of reflections above the BSR are generally reduced compared to those below. For example, consider the true amplitude Profile 92-11 (Fig. 2). With low-power sources, such as ours, deep reflections are weakened by attenuation, but the pattern of reduced amplitudes above the BSR and increased amplitudes below it is apparent in Figure 11. In this plot, large-amplitude reflections near the seafloor no doubt arise from stratigraphic variations. Strong reflections at and just below the BSR (marked X) probably are caused by the presence of free gas trapped in the beds just below the hydrate stability zone, but the zone of free gas may be thin $(<25 \mathrm{~m}$, perhaps $0.02 \mathrm{~s}$; Katzman et al., 1994). Even if free gas exists in a much thicker zone than that (Holbrook et al., in press, suggest presence of a zone at least $200 \mathrm{~m}$ thick), reflections below $\sim 5 \mathrm{~s}(0.3 \mathrm{~s}$ below the BSR) probably represent normal reflection amplitudes and are larger than amplitudes in the hydrate zone. Because of the structure of the Blake Ridge, reflections from continuations of these same deeper reflectors of Figure $11 \mathrm{can}$ be observed where they extend into the hydrate zone above the BSR (Fig. 5). Reflectors represented in the lower part of Figure 11 (shotpoints 2500-2600 on Line 12) show much-reduced reflection amplitudes at their continuation above the BSR at about shotpoints 1000-1300 on the same line (Fig. 3). In profiles collected with high-power seismic sources (e.g., Shipley et al., 1979; Dillon and Popenoe, 1988), amplitudes beneath the BSR are observed to be greater than those above it, even to considerable depths. The reflection marked with a square in Figure 11 is an anomalous event that will be discussed subsequently.

At Sites 994, 995, and 997, near the crest of the Blake Ridge, reflection amplitudes generally decrease downward through the zone of gas hydrate stability and reach a minimum just above the BSR 


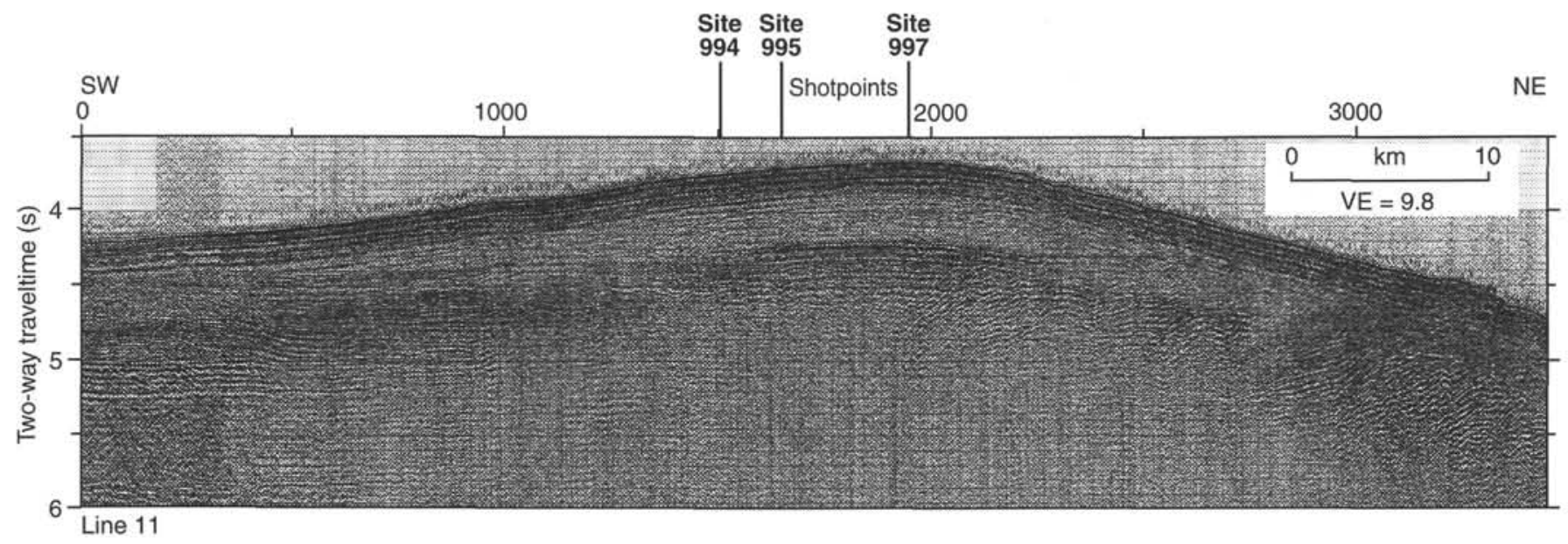

Figure 2. Seismic Profile USGS 92-11. Drill site locations were projected parallel to the crest of the Blake Ridge. VE = vertical exaggeration.

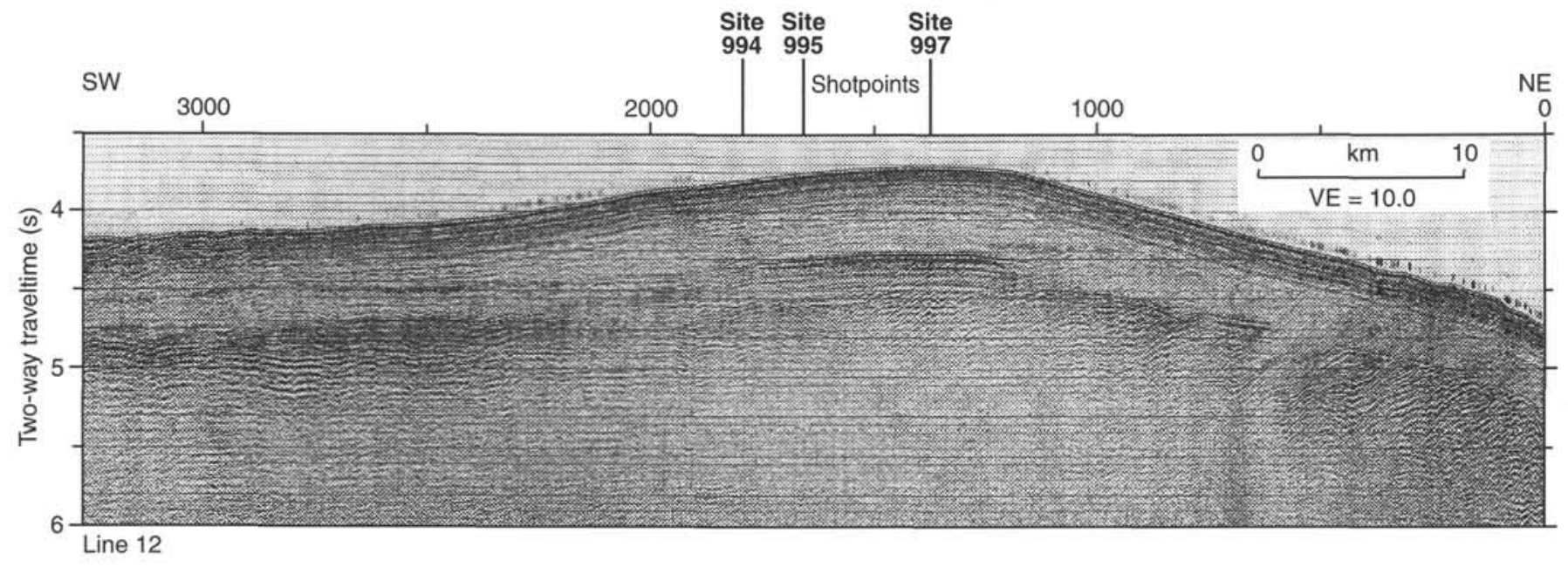

Figure 3. Seismic Profile USGS 92-12. Drill site locations were projected parallel to the crest of the Blake Ridge. VE $=$ vertical exaggeration.

(Fig. 2). A pattern of velocities increasing down to the BSR and decreasing below it is also apparent in the vertical seismic profiling and velocity logging at the two sites where the BSR exists (995 and 997). This pattern is consistent with the vertical distribution of hydrate in the sediments inferred from velocity and from pore-water chloride variations recorded at the drill sites. We infer that the reduction in reflection amplitude, known as "blanking," is the result of the presence of gas hydrate, which increases the velocity of the more porous, lower velocity sedimentary beds by the introduction of a highvelocity material in the pores and thus results in a more uniform velocity for the sedimentary section. Thus, an increase in the amount of gas hydrate should be correlatable to an increase in blanking (Lee et al., 1993, 1994), although this has been disputed (Holbrook et al., in press) based on the VSP results at Sites 994, 995, and 997. Blanking, and by inference the amount of hydrate, appears to increase at locations where a shallowing of the BSR would lead to the trapping of gas and, thus, result in more effective gas recycling into the gas hydrate as the seafloor accretes (Dillon et al., 1994, 1995; Paull et al., 1994). Locations that trap and concentrate gas occur at hills on the seafloor (such as at the Blake Ridge), where the BSR, following the isotherms, is upwarped to form a dome, or at salt diapirs (such as those along the seaward side of the Carolina Trough), where the BSR is upwarped due perhaps to both thermal and chemical effects (Dillon et al., 1993). In contrast, blanking within the zone of gas hydrate stability is very weak in the region from Wilmington Canyon to Cape Hatteras (Dillon et al., 1995), where landslide scars are common. The scars are evidence for mass movements that may have triggered hydrate breakdown due to pressure reduction effects (Carpenter, 1981; Paull et al., 1991; Popenoe et al., 1993; Dillon et al., 1994).

\section{Faults}

\section{Buried Faults}

A pattern of faulting extends across the Blake Ridge in the vicinity of Sites 994,995 , and 997, as indicated in the interpretations of Profiles $92-11$ and $92-12$ (Figs. 4, 5). An enlarged view of part of the faulted section is shown in Figure 10. The faults seem to exist in a zone of uniform thickness of 0.5-0.6 s that, across most of the ridge, extends from within the zone of hydrate stability to below the base of the zone. The top of the zone is $\sim 0.3-0.4 \mathrm{~s}$ below the seafloor on the southwest end of the profiles and deepens (relative to the rising seafloor) toward the ridge crest. On Line USGS 92-11 (Figs. 2, 4), the top of the zone occurs at $\sim 0.7 \mathrm{~s}$ below the seafloor just south of the crest and $0.4 \mathrm{~s}$ just north of the crest. In contrast, the top of the interpreted faulted zone rises more abruptly on Line USGS 92-12 (Figs. 3,5 ) and is $\sim 0.5 \mathrm{~s}$ below the seafloor just south of the ridge crest and $0.2 \mathrm{~s}$ just to the north. Some smaller offsets of strata may exist above the top of the faulted zone; these are considered to be draping effects 


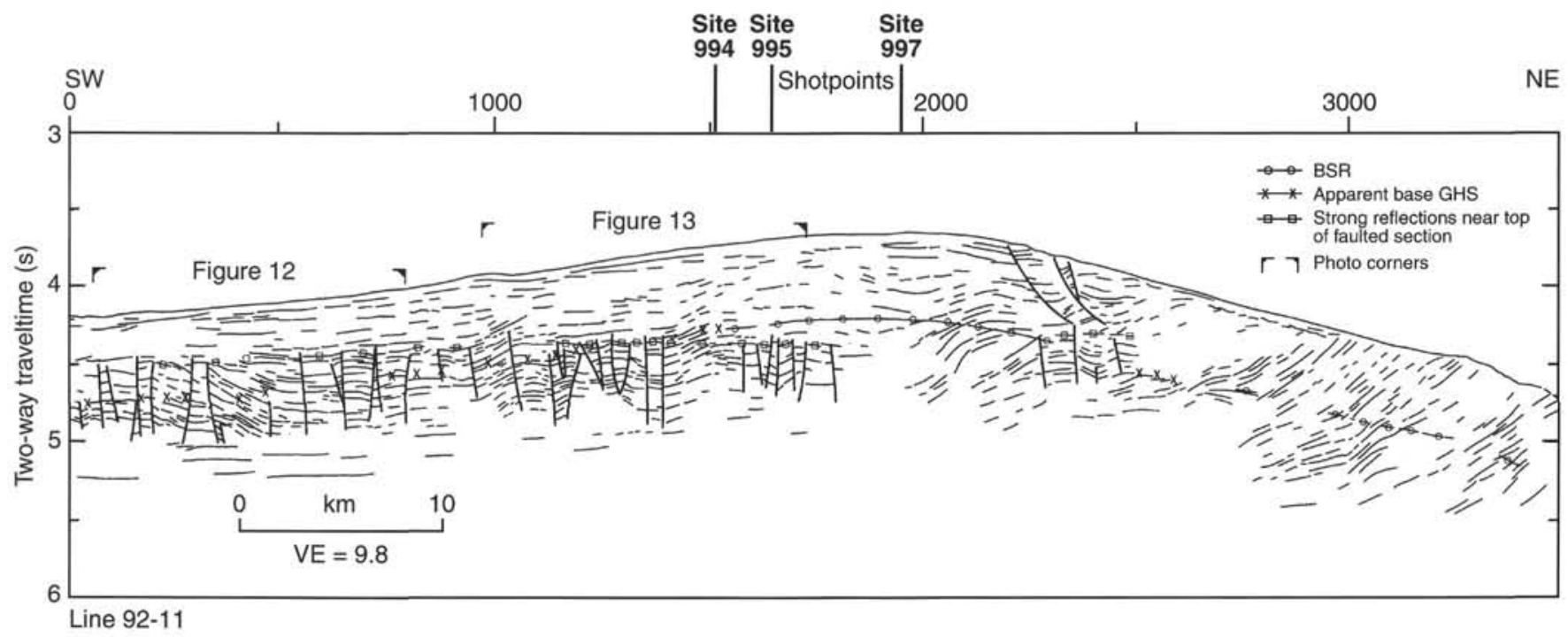

Figure 4. Line drawing interpretation of seismic Profile USGS 92-11 (profile shown in Fig. 2). The reflection indicated as the BSR is a strong, continuous event. The extension of the BSR, where it is disrupted or appears as shingled strong reflections, is indicated as the apparent base of gas hydrate stability. Both of these reflection events are considered to indicate seismic evidence for the bottom of the gas hydrate zone. The location is shown for Sites 994.995 , and 997 , projected parallel to the crest of the Blake Ridge. $\mathrm{VE}=$ vertical exaggeration.

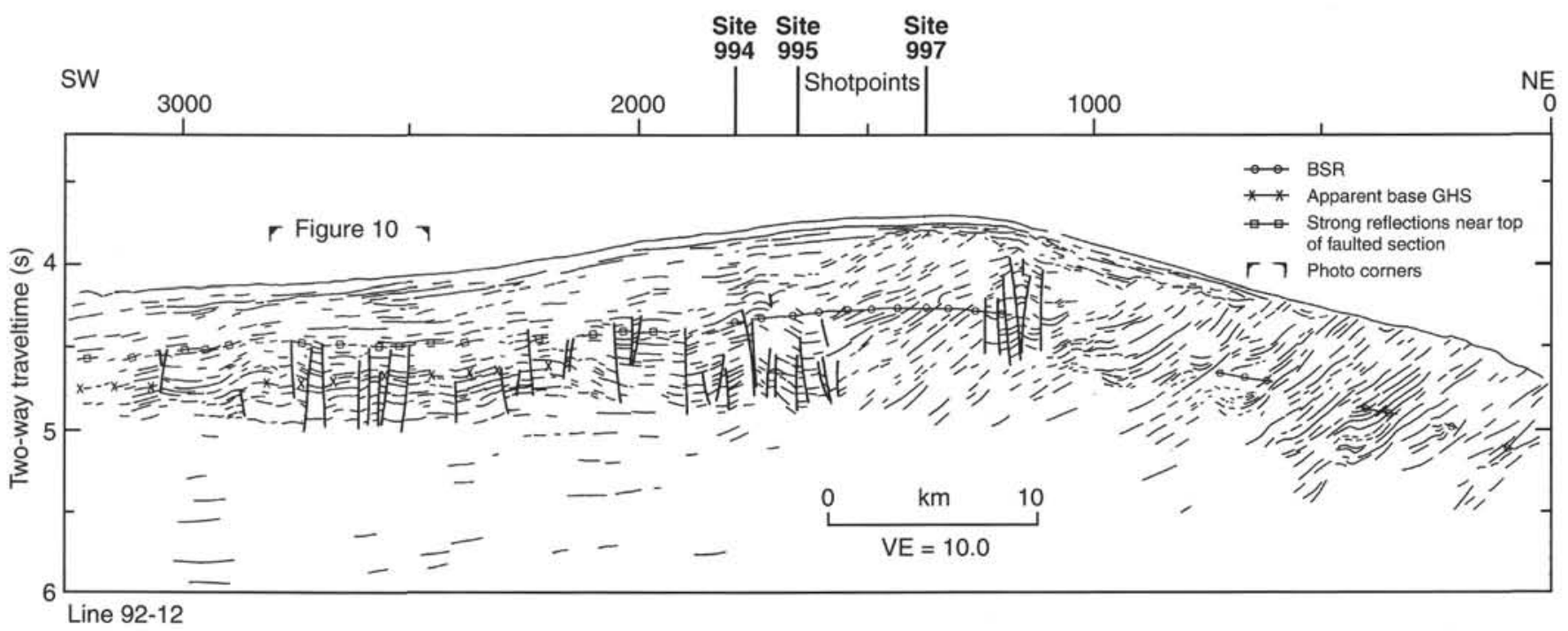

Figure 5. Line drawing interpretation of seismic Profile USGS 92-12 (profile shown in Fig. 3). Symbols are the same as in Figure 4. The locations are shown for ODP Sites 994, 995, and 997, projected parallel to the crest of the Blake Ridge. VE = vertical exaggeration.

or the effect of minor adjustments of fault blocks after the main faulting episode.

The top of the faulted zone approximately parallels the trend of reflections in each line. Note that the reflections dip more steeply, and the top of the faulted zone rises more abruptly beneath the ridge crest in Line $92-12$ than in 92-11. The reflectors are assumed to represent strata; therefore, we suggest that the top of the faulted zone probably represents a time horizon that was the seafloor when the crest of the ridge was further to the northwest. The time thickness of the faulted zone is essentially the same as the present zone of gas hydrate stability. Thus, it seems possible that, at the time of faulting, the faults occurred dominantly in the gas hydrate-bearing zone and extended between the seafloor and the then BSR. The gas hydrate-cemented zone might have faulted independent of deeper strata because the hydrate at the limit of phase stability (at the base of the hydrate stable zone) had broken down because of changing conditions, such as a temperature increase or pressure decrease (caused by sea-level low- ering) and, thus, had decoupled the overlying strata from sediments below. Examples of comparable faulting in more recent strata have been noted by Rowe and Gettrust (1993) elsewhere on the Blake Ridge and also exist near Sites 994, 995, and 997 just northwestward along the ridge (see "Shallow Faults" below).

A few strong reflections mark the top of the faulted zone (Figs. 10-13). These reflection events approximate the appearance of a BSR, although they do not parallel the seafloor. They appear to have reversed polarity compared to the seafloor reflection (Fig. 11 at $\sim 4.5$ $\mathrm{s}$ ), but this is not certain and further work is needed. If polarity is reversed, this implies a negative impedance contrast, most easily explained by the presence of free gas, although that would require an excess of gas, allowed by conversion of all water to hydrate in a local zone.

The top of the faulted zone and the associated strong reflections pass northward from above the base of gas hydrate stability to below it, $\sim 5 \mathrm{~km}$ southwest of the projected location of Site 994 on Profile 


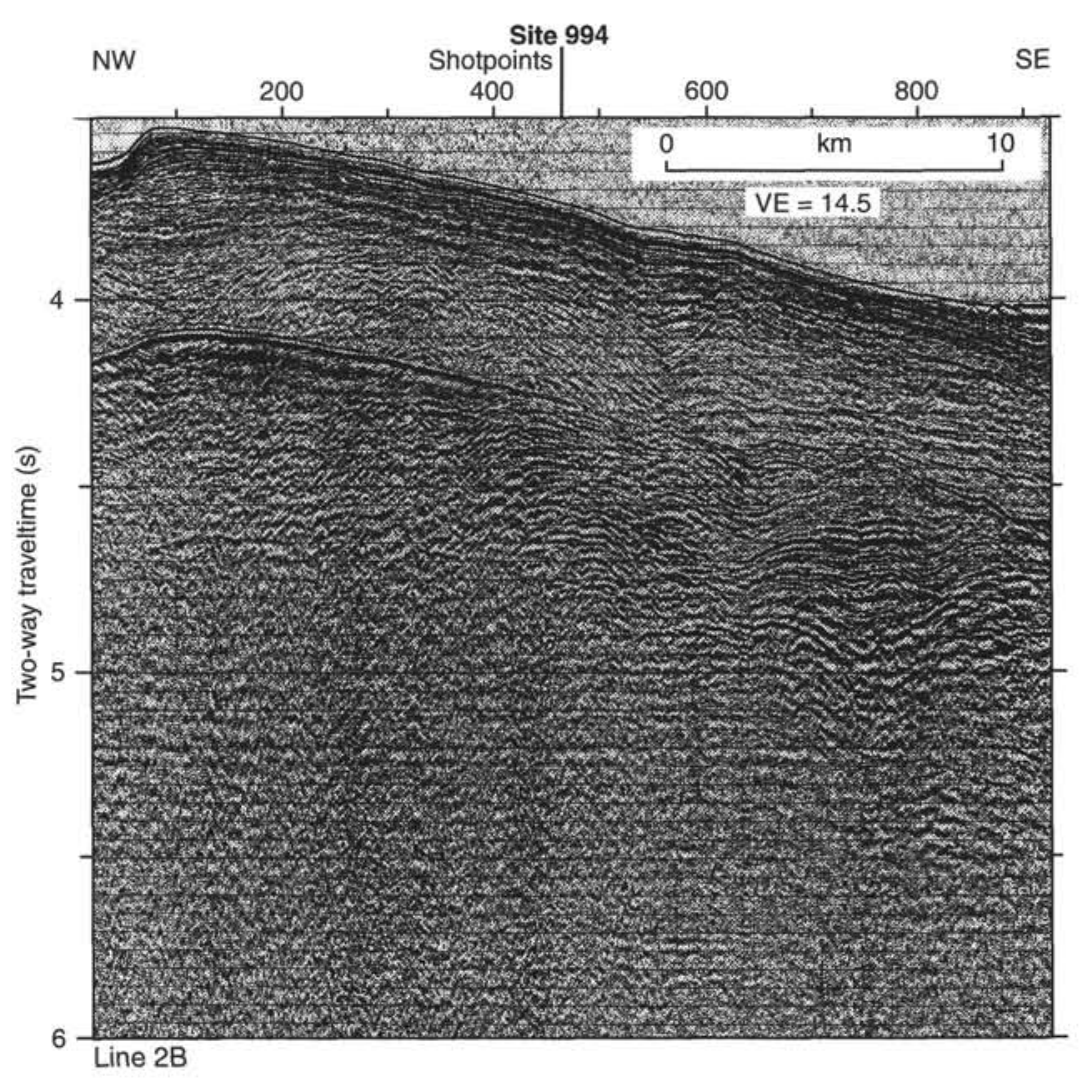

Figure 6. Profile 95-2B. VE = vertical exaggeration.

92-11 (Figs. 2, 4, 13; also see Profile 2A on Fig. 8). At Site 994, we estimate the depth to the strong reflections to be $\sim 530 \mathrm{~m}$ subbottom on the basis of the traveltime-depth curves in the "Geophysics" section of the "Site 994" chapter (this volume). At Site 994, interval velocity derived from vertical seismic profiling (see "Geophysics" section, "Site 994" chapter, this volume) begins to drop precipitously from more than $1800 \mathrm{~m} / \mathrm{s}$ at this depth to slightly more than $1500 \mathrm{~m} / \mathrm{s}$ at the base of the hole. The depth of the projected BSR (base of gas hydrate stability) at the site is $\sim 440 \mathrm{~m}$, but the BSR appears to terminate a short distance toward the ridge crest from the drill site and is not present at Site 994 in most profiles (e.g., Figs. 2, 8, 9, this chapter, and Fig. 1 in Section 2, this volume). No downward decrease in velocity is indicated at the level of the inferred base of hydrate stability (see "Geophysics" section, "Site 994" chapter, this volume). At Site 995, the BSR is well developed and a velocity decrease occurs at that level, but a secondary further decrease in velocity appears at $\sim 550 \mathrm{~m}$ subbottom and seems to correlate with the top of faulting (see "Geophysics" section, "Site 995" chapter, this volume; Figs. 2, 9, this chapter; and Fig. 1 in Section 2, this volume) At Site 997, the top of the faulted zone seems to be near the BSR and is lost in the strong blanking above and strong reflections below the BSR (Figs. 3, 9, this chapter; also see Fig. 1 in Section 2, this volume).

Thus, strong reflections, polarity reversal and low velocity appear to be associated with the top of the faulted zone, both above and below the base of gas hydrate stability. We speculate that gas may have migrated up the faults to some permeability barrier at the top of the zone and has become trapped there, both where the top of faulting is above the base of gas hydrate stability and where it is below that level. Above the base of gas hydrate stability, this apparently would require a large amount of gas that, in a small region, used up all the water in forming hydrate, allowing the excess to collect as free gas.

\section{Shallow Faults}

Faults that cut the seafloor northeast of the ridge crest appear in Profile 92-11 (Figs. 2, 4). These faults are related to an extensive re- gion of recent faulting that disrupts the seafloor and is indicated by the irregular contours in the northwest corner of Figure 1. The depression of the seafloor at the northwest ends of Profiles $2 \mathrm{~B}$ and 5 is part of a complex graben associated with this faulting.

\section{SUMMARY AND CONCLUSIONS}

1. The Blake Ridge displays the structure of a southwestwardmigrating sediment drift.

2. A strong, continuous BSR exists near the ridge crest, where free-gas concentrations beneath the BSR appear to be greatest. On the flanks of the ridge the BSR is discontinuous, at some locations because the base of gas hydrate stability passes through dipping strata, and elsewhere because the strata are disrupted by faulting.

3. A decrease in reflection amplitude, known as blanking, is observed in reflections from within the zone of gas hydrate stability. We infer that blanking is caused by cementation of strata by gas hydrate, and thus the intensity of blanking may reflect the amount of gas hydrate present. Both the presence of blanking and this inference are controversial, however. Vertically, blanking is correlated, in a general way, with variations in gas hydrate concentration that are noted from drilling results-both blanking and hydrate concentration increase downward toward the BSR. Laterally, variations in blanking suggest that concentrations of gas hydrate are greater at the Blake Ridge than elsewhere on the U.S. Atlantic continental margin and that hydrate is concentrated toward the crest of the Blake Ridge.

4. A zone of minor faulting extends across the Blake Ridge in the region of Sites 994, 995, and 997. Across most of the ridge, the top of the faulted zone is above the base of gas hydrate stability (BSR), but at the ridge crest, near Site 994, the top of the faulted section dips below the BSR. The thickness of the faulted zone is about the same as the present hydrate stable zone. We hypothesize that the top of the faulted zone was the seafloor at the time of faulting and that the base of the zone was the base of gas hydrate stability. Such a pattern of faulting that extends across a vertical distance roughly equivalent to 
Figure 7. Profile 95-5. VE = vertical exaggeration.

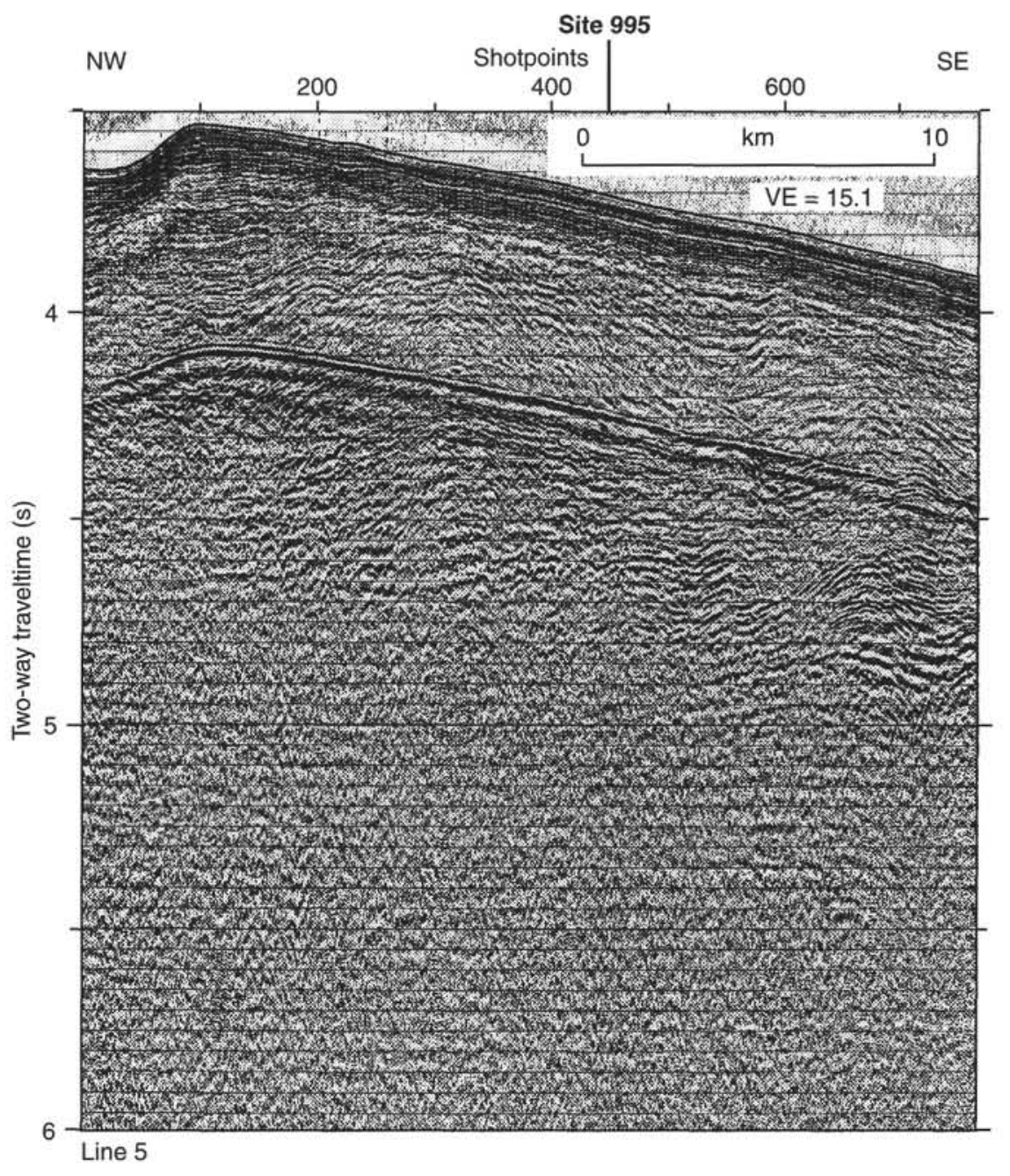

the zone of expected gas hydrate stability might be considered to be a piece of evidence for former presence of gas hydrate in old rocks.

5 . The top of the faulted zone is marked by a very strong set of reflections and the top of the zone passes continuously from beneath the base of gas hydrate stability at Site 994 to above the base further down the flank of the ridge. Near the ridge crest, the level of the top of the zone correlates to a major downward decrease in interval velocity at Site 994, and to a lesser extent at Site 995 (see "Geophysics" sections, "Site 994" and "Site 995" chapters, this volume). On the ridge flank, consideration of the waveform suggests that a phase reversal may occur compared to the seafloor reflection, which also suggests a velocity decrease downward. Such a velocity inversion at the top of the faulted zone is consistent with the presence of trapped gas both below and above the base of hydrate stability.

\section{ACKNOWLEDGMENTS}

We wish to thank the scientific parties and crews for their efforts under difficult sea conditions aboard the Cape Hatteras during cruises CH 12-92 and CH 18-95. We especially thank Thomas O'Brien. Participation in the series of 1995 cruises by Joseph Gettrust, Mary Rowe, and staff of the U.S. Naval Research Laboratory, Stennis Space Center, Mississippi, and funding from the Office of Naval Re- search and National Science Foundation are gratefully acknowledged. Graphics were well prepared by Jeffrey Zwinakis and Dann Blackwood. Valuable reviews were provided by Elazar Uchupi, John Schlee, and Warren Wood.

\section{REFERENCES}

Brandt, H., 1960. Factors affecting compressional wave velocity in unconsolidated marine sand sediments. J. Acoust. Soc. Am., 32:171-179.

Bryan, G.M., 1970. Hydrodynamic model of the Blake Outer Ridge. J. Geophys. Res., 75:4530-4537.

Buffler, R.T., Shipley, T.H., and Watkins, J.S., 1978. Blake continental margin seismic section. AAPG, Seismic Sec. 2.

Carpenter, G.B., 1981. Coincident sediment slump/clathrate complexes on the U.S. Atlantic continental slope. Geo-Mar. Lett., 1:29-32.

Dillon, W.P., Fehlhaber, K., Coleman, D.F., Lee, M.W., and Hutchinson, D.R., 1995. Maps showing gas hydrate distribution off the east coast of the United States. USGS Misc. Field Studies Map, 2268.

Dillon, W.P., Grow, J.A., and Paull, C.K., 1980. Unconventional gas hydrate seals may trap gas off the southeastern U.S. Oil \& Gas J., 78:124-130.

Dillon, W.P., Lee, M.W., and Coleman, D.F., 1994. Identification of marine hydrates in situ and their distribution off the Atlantic coast of the United States. In Sloan, E.D., Jr., Happel, J., and Hnatow, M.A. (Eds.), Int. Conf. Natural Gas Hydrates, Ann. N.Y. Acad. Sci., 715:364-380.

Dillon, W.P., Lee, M.W., Fehlhaber, K., and Coleman, D.F., 1993. Gas hydrates on the Atlantic margin of the United States-controls on con- 
centration, In Howell, D.G. (Ed), The future of energy gases. Geol. Surv. Prof. Pap., 1570:313-330.

Dillon, W.P., and Paull, C.K., 1983. Marine gas hydrates, II. Geophysical evidence. In Cox, J.L. (Ed.), Natural Gas Hydrates: Properties, Occurrences, and Recovery: Woburn, MA (Butterworth), 73-90.

Dillon, W.P., and Popenoe, P., 1988. The Blake Plateau basin and Carolina Trough. In Sheridan, R.E., and Grow, J.A. (Eds.), The Atlantic Continental Margin, U.S., Geol. Soc. Am., Geology of North America, I-2:291328.

Dillon, W.P., Popenoe, P., Grow, J.A., Klitgord, K.D., Swift, B.A., Paull, C.K., and Cashman, K.V., 1982. Growth faulting and salt diapirism: their relationship and control in the Carolina Trough, Eastern North America. In Watkins, J.S., and Drake, C.L. (Eds.), Studies of Continental Margin Geology. AAPG Mem., 34:21-46.

Ewing, J.I., and Hollister, C.H., 1972. Regional aspects of deep-sea drilling in the western North Atlantic. In Hollister, C.D., Ewing, J.I., et al., Init. Repts. DSDP, 11: Washington (U.S. Govt. Printing Office), 951-973.

Holbrook, W.S., Hoskins, H., Wood, W.T., Stephen, R.A., and the Leg 164 Science Party, in press. Methane hydrate and free gas on the Blake Ridge from vertical seismic profiling. Science.

Hollister, C.D., Ewing, J.I., et al., 1972. Init. Repts. DSDP, 11: Washington (U.S. Govt. Printing Office).

Hutchinson, D.R., Grow, J.A., Klitgord, K.D., and Swift, B.A., 1982. Deep structure and evolution of the Carolina Trough. In Watkins, J.S., and Drake, C.L. (Eds.), Studies of Continental Margin Geology. AAPG Mem., 34:129-152.

Katzman, R., Holbrook, W.S., and Paull, C.K., 1994. A combined vertical incidence and wide-angle seismic study of a gas hydrate zone, Blake Outer Ridge. J. Geophys. Res., 99:17975-17995.

Klitgord, K.D., Hutchinson, D.R, and Schouten, H., 1988. U.S. Atlantic continental margin: structural and tectonic framework. In Sheridan, R.E., and Grow, J.A., (Eds.), The Atlantic Continental Margin, U.S., Geol. Soc. Am., Geology of North America, I-2:19-53.

Krason, J., and Ridley, W.I., 1985. Geological evolution and analysis of confirmed or suspected gas hydrate localities, (Vol. 1): Blake-Bahama Outer Ridge-U.S. East Coast: Denver (Geoexplorers Intl., Inc., for U.S. Dept. of Energy).

Kvenvolden, K.A., and Barnard, 1983. Gas hydrates of the Blake Outer Ridge, Site 533, Deep Sea Drilling Project Leg 76. In Sheridan, R.E. and Gradstein, F.M., et al., Init. Repts. DSDP, 76: Washington (U.S. Govt. Printing Office), $353-365$.

Lancelot, Y., and Ewing, J.I., 1972. Correlation of natural gas zonation and carbonate diagenesis in Tertiary sediments from the north-west Atlantic. In Hollister, C D., Ewing, J.I., et al., Init. Repts. DSDP, 11: Washington (U.S. Govt. Printing Office), 791-799.

Lee, M.W., Hutchinson, D.R., Agena, W.F., Dillon, W.P., Miller, J.J., and Swift, B.A., 1994. Seismic character of gas hydrates on the southeastern U.S. continental margin. Mar. Geophys. Res., 16:163-184.
Lee, M.W., Hutchinson, D.R., Dillon, W.P., Miller, J.J., Agena, W.F., and Swift, B.A., 1993. Method of estimating the amount of in situ gas hydrates in deep marine sediments. Mar. Pet. Geol., 10:493-506.

Markl, R.G., Bryan, G.M., and Ewing, J.I., 1970. Structure of the BlakeBahama Outer Ridge. J. Geophys. Res., 75:4539-4555.

McCave, I.N., and Tucholke, B.E., 1986. Deep current-controlled sedimentation in the western North Atlantic. In Vogt, P.R., and Tucholke, B.E. (Eds.), The Western North Atlantic Region. Geol. Soc. Am., Geol. of North American Ser., M:451-468.

Mountain, G.S., and Tucholke, B.E., 1985. Mesozoic and Cenozoic geology of the U.S. Atlantic continental slope and rise. In Poag, C.W. (Ed.), Geologic Evolution of the United States Atlantic Margin: New York (Van Nostrand Reinhold), 293-341.

Paull, C.K., and Dillon, W.P., 1981. Appearance and distribution of the gas hydrate reflection in the Blake Ridge region, offshore southeastern United States. USGS Misc. Field Studies Map, 1252.

Paull, C.K., Ussler, W., III, and Borowski, W.A., 1994. Sources of biogenic methane to form marine gas hydrates: in situ production or upward migration? Ann. N.Y. Acad. Sci., 715:392-409.

Paull, C.K., Ussler, W., III, and Dillon W.P., 1991. Is the extent of glaciation limited by marine gas-hydrates? Geophys. Res. Lett., 18:432-434.

Popenoe, P., Schmuck, E.A., and Dillon, W.P., 1993. The Cape Fear landslide: slope failure associated with salt diapirism and gas hydrate decomposition. In Schwab, W.C., Lee, H.J. and Twichell, D.C., (Eds.), Submarine landslides: Selected studies in the U.S. Exclusive Economic Zone. U.S. Geol. Surv. Bull., 2002:40-53.

Rowe, M.M., and Gettrust, J.F., 1993. Fine structure of methane hydratebearing sediments on the Blake Outer Ridge as determined from deeptow multichannel seismic data. J. Geophys. Res., 98:463-473.

Ruppel, C., Von Herzen, R.P., and Bonneville, A., 1995. Heat flux through an old ( 175 Ma) passive margin: offshore southeastern United States. $J$. Geophys. Res., 100:20037-20057.

Sheridan, R.E., Gradstein, F.M., et al., 1983. Init. Repts. DSDP, 76: Washington (U.S. Govt. Printing Office).

Shipley, T.H., Houston, M.H., Buffler, R.T., Shaub, F.J., McMillen, K.J., Ladd, J.W., and Worzel, J.L., 1979. Seismic evidence for widespread possible gas hydrate horizons on continental slopes and rises. AAPG Bull., 63:2204-2213.

Stoll, R.D., Ewing, J.I., and Bryan, G.M., 1971. Anomalous wave velocities in sediments containing gas hydrates, J. Geophys. Res., 76:2090-2094.

Tucholke, B.E., Bryan, G.M., and Ewing, J.I., 1977. Gas-hydrate horizons detected in seismic-profiler data from the western North Atlantic. AAPG Bull., 61:698-707.

\section{Ms 164IR-104}


Figure 8. Profile 95-2A. VE $=$ vertical exaggeration.

Figure 9. Profile 95-1. VE = vertical exaggeration.
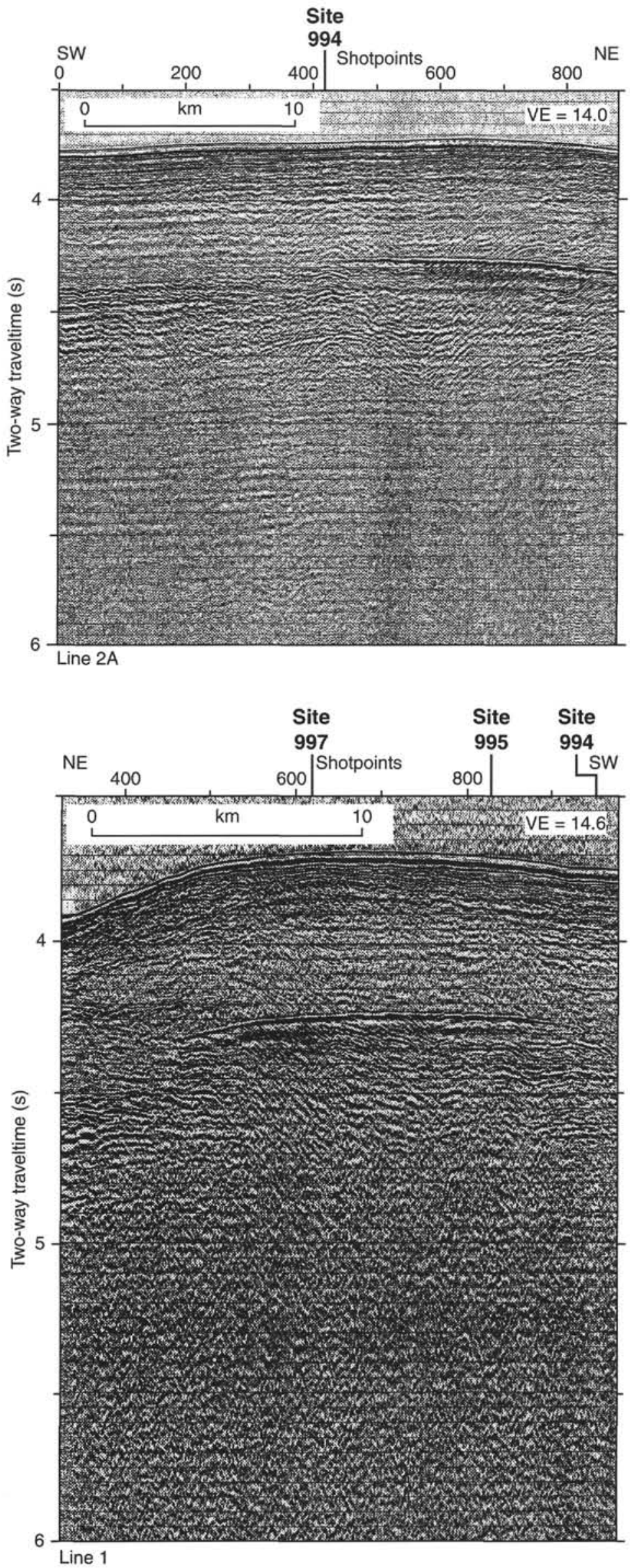

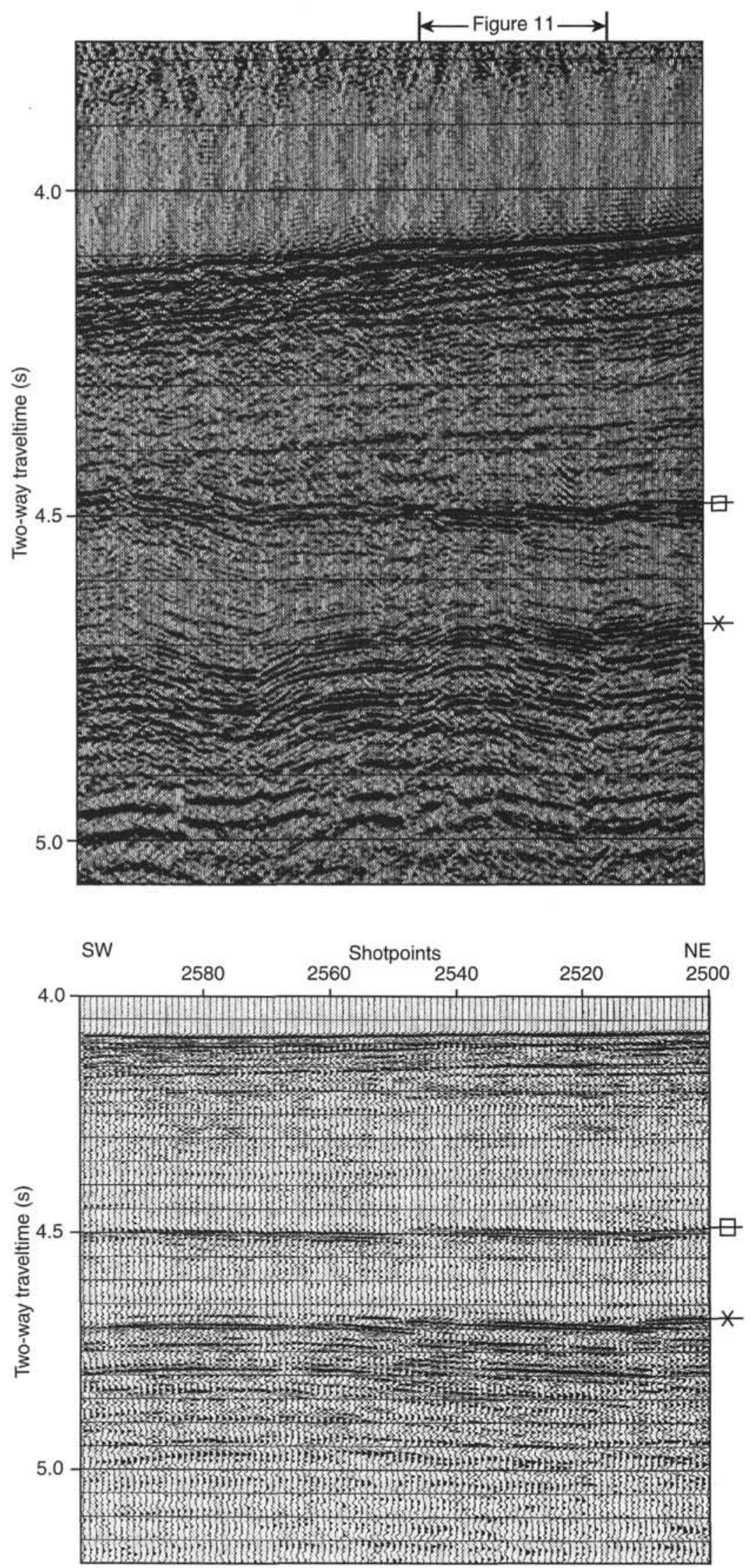

Line 92-12
Figure 10. Enlarged view of part of Profile 92-12 (location shown by photo corner bracket on Fig. 5). Faulted section occurs below $\sim 4.5 \mathrm{~s}$. Symbols are the same as in Figure 4 .
Figure 11. Expanded wiggle-trace true amplitude presentation of 100 shots from Profile 12 (location shown on Fig. 10). Symbols are the same as in Figure 4. 
Figure 12. Enlarged view of part of Profile 92-11 (location shown by photo corner bracket on Fig. 4). The BSR occurs at $4.7 \mathrm{~s}$, and strong reflections at the top of the faulted zone occur at 4.4-4.5 s. Symbols are the same as in Figure 4.

Figure 13. Enlarged view of part of Profile 92-11 (location shown by photo corner bracket on Fig. 4). In this region, the base of hydrate stability, shown by the BSR and the extended base of gas hydrate, which does not display a strong BSR, dip left and intersect the strong reflections at the top of the faulted zone. Symbols are the same as in Figure 4. Site 994 was drilled near this profile, and the well passed through the level of the base of gas hydrate stability, which did not show a strong BSR reflection at the drill site, without displaying any decrease of seismic velocity (see "Geophysics" section, "Site 994" chapter, this volume). A decrease in velocity was noted at a depth equivalent to the strong reflections at the top of the faulted zone, suggesting that this level is the shallowest concentration of free gas at the site.
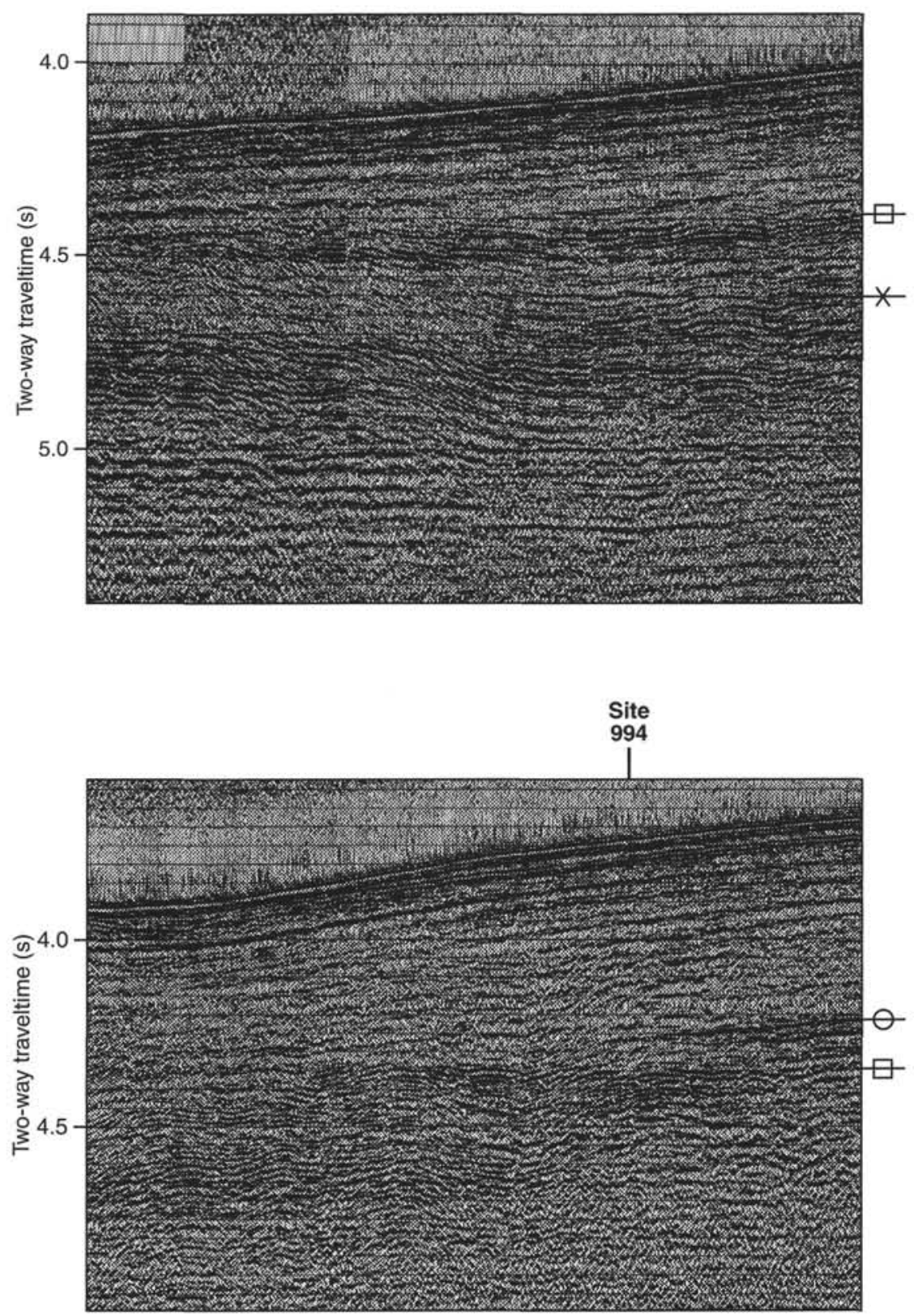